\title{
PROGNOSTIC SIGNIFICANCE OF C-REACTIVE PROTEIN IN ACUTE STROKE
}

\author{
Philomena James ${ }^{1}$, Rangaswami Mangalasundaram², Arun Natesh Radhakrishnan ${ }^{3}$
}

${ }^{1}$ Associate Professor, Department of General Medicine, Government Vellore Medical College.

${ }^{2}$ Assistant Professor, Department of General Medicine, Government Vellore Medical College.

${ }^{3}$ Post Graduate, Department of General Medicine, Government Vellore Medical College.

ABSTRACT
BACKGROUND
Cerebrovascular stroke is one of the leading cause of death and disability. C-Reactive Protein is an inflammatory marker that is
increased in stroke. We intended to study the role of CRP in predicting severity and short-term outcome in stroke patients.

\section{METHOD}

The study included 60 patients with acute stroke admitted within 24 hours of symptom onset. All patients were subjected to detailed history taking and neurological evaluation. Severity of stroke on admission was assessed with National Institute of Health Stroke Scale (NIHSS), while seven days later outcome was assessed with modified Rankin Score (mRS) and Barthel ADL Index (BI). CRP levels and CT Brain was done in all patients within 24 hours of admission.

\section{RESULTS}

The mean age of the patients was $62.53 \pm 9.54$. We found that CRP levels on admission was higher in ischaemic stroke patients (Mean=8.56 \pm 3.51 ) and there was positive correlation between CRP levels and severity assessed by NIHSS ( $r=0.44 ; p=0.004)$. There was positive correlation between CRP levels and short-term outcome assessed by $m R S(r=0.35$; $p$ value $=0.022)$. However, there was no positive correlation between CRP levels and severity or outcome in haemorrhagic stroke patients.

\section{CONCLUSION}

CRP levels on admission is a predictor of severity and short-term outcome in ischaemic stroke, but not haemorrhagic stroke.

\section{KEYWORDS}

C-Reactive Protein, Cerebrovascular Stroke, NIHSS.

HOW TO CITE THIS ARTICLE: James P, Mangalasundaram R, Radhakrishnan AN. Prognostic significance of c-reactive protein in acute stroke. J. Evolution Med. Dent. Sci. 2016;5(53):3549-3555, DOI: 10.14260/jemds/2016/818

\section{INTRODUCTION}

C-reactive protein is a marker of inflammation. It is a glycoprotein synthesized by the liver in response to cytokines produced by macrophages. Recent evidences suggest that it is also associated with atherosclerosis. This led to studies focussing on CRP as an indicator of prognosis for vascular events.

Cerebrovascular Accidents, both ischaemic and haemorrhagic stroke have been one of the leading causes of mortality and morbidity in elderly populations.[1] However, markers predicting prognosis in these patients have not been established clearly.

The relationship between inflammation and atherosclerosis is well established. Thus, CRP being a marker of inflammation is identified as a marker for prognosis after vascular events. In addition elevated levels of CRP has also been used as an indicator of future vascular events.

The rise in CRP levels in stroke is not only due to its association with atherosclerosis, but also due to the inflammatory reaction that follows tissue damage.[2]

Financial or Other, Competing Interest: None.

Submission 04-06-2016, Peer Review 16-06-2016,

Acceptance 17-06-2016, Published 04-07-2016.

Corresponding Author:

Dr. Philomena James,

\#14, JP Salai,

Thendral Nagar,

Sathuvachari, Vellore-9.

E-mail: indian7@gmail.com

DOI: $10.14260 /$ jemds $/ 2016 / 818$
Thus, explaining its potential to be a marker for prognosis following vascular events. The increased CRP levels causes activation of complement leading to secondary brain damage. [3]

Various studies have been done to establish correlation between CRP and stroke. Though it is less extensively studied when compared to CRP association in coronary artery disease, results from some of these studies show a positive association between CRP and stroke. The Framingham study found that high levels of CRP correlated with greater risk of ischaemic stroke or TIA.[4] The Rotterdam study found that CRP levels were not useful for future stroke prediction. [5]

Most of the studies were done in ischaemic stroke patients. The association between CRP levels and haemorrhagic stroke is not well studied. CRP levels in haemorrhagic stroke could be elevated due to inflammatory reaction elicited by haematoma.[6]

Thus, in pursuit of further knowledge into the role of $\mathrm{C}$ Reactive Protein in patients with stroke, we undertook this study.

\section{AIM OF THE STUDY}

This study is done to establish the role of CRP, measured within 24 hours of onset of stroke as an indicator for assessing stroke severity and its short-term outcome.

\section{METHOD OF STUDY}

The study included patients admitted with first episode of acute stroke within 24 hours of onset to the Department of Medicine, Government Vellore Medical College. 
The study was conducted from February 2016 to March 2016. Patients with onset of symptoms more than 24 hours, recent history of traumatic brain injury, cerebrovascular events, acute coronary syndrome, liver cell failure and autoimmune diseases were excluded from the study.

The study design was submitted to the Institutional Ethical Committee and approval obtained. Informed written consent obtained from all patients or their relatives to participate and to publish the data.

Detailed history with emphasis on smoking (Number of packets of cigarette smoked per day times number of yearsPack Years), Hypertension (Patients who are on antihypertensives or documented Systolic BP $\geq 140 \mathrm{mmHg}$ and/or Diastolic BP $\geq 90 \mathrm{mmHg}$ ), Dyslipidaemia and Diabetes mellitus (Patient on treatment for diabetes or diagnosed during hospital stay).

All patients underwent thorough neurologic examination and severity on admission was assessed using National Institute of Health Stroke Scale (NIHSS). Outcome was evaluated 7 days later using Modified Rankin Scale (mRS) and Barthel ADL Index (BI). Tables 1, 2 and 3 show the components of NIHSS, mRS and BI respectively.

CT-Brain was done to differentiate Ischaemic and Haemorrhagic stroke. Blood samples were taken on the day of admission for routine laboratory investigations and CRP assay. Solid phase ELISA was used to calculate CRP and normal reference value was less than $6 \mathrm{mg} / \mathrm{L}$.

\begin{tabular}{|c|c|c|}
\hline Instructions & Scale Definition & Score \\
\hline 1a. Level of Consciousness & $\begin{aligned} 0= & \text { Alert } \\
1= & \text { Not alert; but arousable by minor stimulation } \\
& \text { to obey, answer or respond } \\
2= & \text { Not alert; requires repeated stimulation to attend, } \\
& \text { or is obtunded and requires strong or painful } \\
& \text { stimulation to make movements (Not stereotyped) } \\
3= & \text { Responds only with reflex motor or autonomic } \\
& \text { effects or totally unresponsive, flaccid, and areflexic }\end{aligned}$ & ......... \\
\hline $\begin{array}{l}\text { 1b. LOC Questions: The patient is asked the month and } \\
\text { his/her age. The answer must be correct }\end{array}$ & $\begin{array}{l}0=\text { Answers both questions correctly } \\
1=\text { Answers one question correctly } \\
2=\text { Answers neither question correctly }\end{array}$ & ......... \\
\hline $\begin{array}{l}\text { 1c. LOC Commands: The patient is asked to open and close } \\
\text { the eyes and then to grip and release the non-paretic } \\
\text { hand. Substitute another one step command if the } \\
\text { hands cannot be used. }\end{array}$ & $\begin{array}{l}0=\text { Performs both tasks correctly } \\
1=\text { Performs one task correctly } \\
2=\text { Performs neither task correctly }\end{array}$ & ......... \\
\hline $\begin{array}{l}\text { 2. Best Gaze: Only horizontal eye movements will be } \\
\text { tested. Voluntary or reflexive (Oculocephalic) eye } \\
\text { movements will be scored, but caloric testing is not } \\
\text { done. }\end{array}$ & $\begin{aligned} 0= & \text { Normal } \\
1= & \text { Partial gaze palsy; gaze is abnormal in one or both } \\
& \text { eyes, but forced deviation and total gaze paresis is } \\
& \text { not present } \\
2= & \text { Forced deviation, or total gaze paresis not overcome } \\
& \text { by the oculocephalic manoeuver }\end{aligned}$ & ......... \\
\hline $\begin{array}{l}\text { 3. Visual: Visual fields (Upper and lower quadrants) are } \\
\text { tested by confrontation, using finger counting or visual } \\
\text { threat as appropriate. Patients may be encouraged, but } \\
\text { if they look at the side of the moving fingers } \\
\text { appropriately this can be scored as normal. }\end{array}$ & $\begin{array}{l}0=\text { No visual loss } \\
1=\text { Partial hemianopia } \\
2=\text { Complete hemianopia } \\
3=\text { Bilateral hemianopia } \\
\quad \text { (Blind including cortical blindness) }\end{array}$ & ......... \\
\hline 4. Facial Palsy & $\begin{aligned} 0= & \text { Normal symmetrical movements } \\
1= & \text { Minor paralysis } \\
& \text { (Flattened nasolabial fold, asymmetry on smiling) } \\
2= & \text { Partial paralysis } \\
& \quad \text { (Total or near-total paralysis of lower face) } \\
3= & \text { Complete paralysis of one or both sides (absence of } \\
& \text { facial movement in the upper and lower face) }\end{aligned}$ & …..... \\
\hline 5. Motor Arm & $\begin{aligned} 0= & \text { No drift; limb holds } 90 \text { (or } 45 \text { ) degrees for full } 10 \mathrm{~s} \\
1 \text { = } & \text { Drift; limb holds } 90 \text { (or } 45 \text { ) degrees, but drifts down } \\
& \text { before full } 10 \text { s; does not hit bed or other support } \\
2 \text { = } & \text { Some effort against gravity; limb cannot get to or } \\
& \text { maintain (If cued) } 90 \text { (or } 45 \text { ) degrees, drifts down to } \\
& \text { bed, but has some effort against gravity } \\
3= & \text { No effort against gravity; limb falls } \\
4= & \text { No movement } \\
& \text { UN = Amputation or joint fusion, explain }\end{aligned}$ & …..... \\
\hline
\end{tabular}




\begin{tabular}{|c|c|c|}
\hline Instructions & Scale Definition & Score \\
\hline 6. Motor Leg & $\begin{aligned} 0= & \text { No drift; leg holds } 30 \text {-degree position for full } 5 \mathrm{~s} \\
1= & \text { Drift; leg falls by the end of the } 5 \mathrm{~s} \text { period, but does not } \\
& \text { hit bed } \\
2= & \text { Some effort against gravity; leg falls to bed by } 5 \mathrm{~s} \text {, but has } \\
& \text { Some effort against gravity } \\
3= & \text { No effort against gravity; leg falls to } \\
& \text { bed immediately } \\
4= & \text { No movement } \\
& \text { UN = Amputation or joint fusion, explain: }\end{aligned}$ & $\ldots \ldots .$. \\
\hline 7. Limb Ataxia & $\begin{aligned} 0= & \text { Absent } \\
1= & \text { Present in one limb } \\
2= & \text { Present in two limbs } \\
& \text { UN = Amputation or joint fusion }\end{aligned}$ & ......... \\
\hline 8. Sensory & $\begin{array}{l}0=\text { Normal; no sensory loss } \\
1=\text { Mild-to-moderate sensory loss } \\
2=\text { Severe-to-total sensory loss }\end{array}$ & .......... \\
\hline 9. $\quad$ Best Language & $\begin{array}{l}0=\text { No aphasia } \text { normal } \\
1=\text { Mild-to-moderate aphasia } \\
2=\text { Severe aphasia } \\
3=\text { Mute, global aphasia; no usable speech or auditory } \\
\quad \text { comprehension }\end{array}$ & $\ldots \ldots$ \\
\hline 10. Dysarthria & $\begin{aligned} 0= & \text { Normal } \\
1= & \text { Mild-to-moderate dysarthria } \\
2= & \text { Severe dysarthria } \\
& \text { UN = Intubated or other physical barrier, } \\
& \text { explain:................... }\end{aligned}$ & $\ldots \ldots$ \\
\hline 11. Extinction and Inattention (Formerly Neglect) & $\begin{aligned} 0= & \text { No abnormality } \\
1= & \text { Visual, tactile, auditory, spatial or personal inattention or } \\
& \text { extinction to bilateral simultaneous stimulation in one of } \\
& \text { the sensory modalities } \\
2= & \text { Profound hemi-inattention or extinction to more than } \\
& \begin{array}{l}\text { one modality; does not recognize own hand or orients to } \\
\text { only one side of space }\end{array}\end{aligned}$ & ......... \\
\hline
\end{tabular}

\begin{tabular}{|c|l|}
\hline Score & \multicolumn{1}{|c|}{ Description } \\
\hline 0 & No symptoms at all \\
\hline 1 & No significant disability despite symptoms; able to carry out all usual duties and activities \\
\hline 2 & Slight disability; unable to carry out all previous activities, but able to look after own affairs without assistance \\
\hline 3 & Moderate disability; requiring some help, but able to walk without assistance \\
\hline 4 & $\begin{array}{l}\text { Moderately severe disability; unable to walk without assistance and unable to attend to own bodily needs } \\
\text { without assistance }\end{array}$ \\
\hline 5 & Severe disability; bedridden, incontinent and requiring constant nursing care and attention \\
\hline 6 & Dead \\
\hline & \multicolumn{1}{c|}{ Table 2: The Main Items of the Modified Rankin Scale } \\
\hline
\end{tabular}

\begin{tabular}{|l|l|}
\hline \multicolumn{1}{|c|}{ Activity } & Score \\
\hline Feeding & \\
\hline $0=$ Unable & \\
$5=$ Needs help cutting, spreading butter, etc., or requires modified diet & \\
$10=$ Independent & \\
\hline Bathing & \\
\hline $0=$ Dependent & \\
$5=$ Independent (Or in shower) & \\
\hline Grooming & \\
\hline $0=$ Needs to help with personal care & \\
$5=$ Independent face/hair/teeth/shaving (Implements provided) & \\
\hline
\end{tabular}




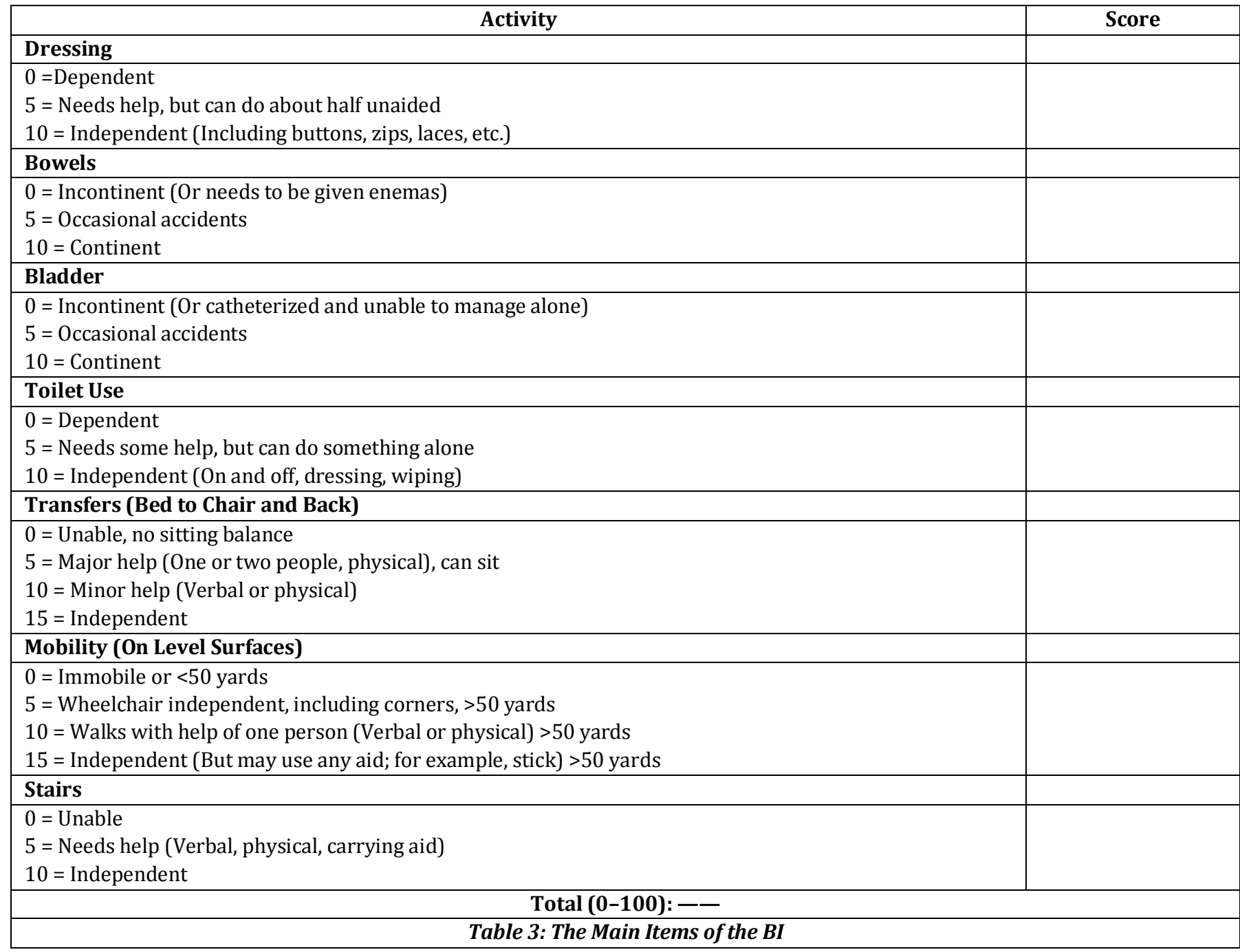

\section{Statistics}

Data were prospectively collected and coded prior to analysis using the professional Statistical Package for Social Science (SPSS version 22). The description of data was in the form of mean ( \pm ) SD for quantitative data and frequency and proportion for qualitative data. Student- $t$ Test $(t)$ and oneway ANOVA was used for comparison between two groups and three groups regarding normally distributed (Parametric) quantitative data. Results were considered significant if $\mathrm{p}<=0.05$.

\section{RESULTS}

The study involved 60 patients who were admitted within 24 hours of onset of acute stroke. Out of the 60 patients, 39 were male and 21 were female. The mean age of patients was $62.53 \pm 9.54$. Based on CT Brain done at the time of admission, 41 patients had ischaemic stroke and 19 patients had haemorrhagic stroke. Table 4 and 5 shows the general characteristics of the study population.

\begin{tabular}{|c|c|}
\hline Parameter & Mean \pm SD \\
\hline Age & $62.53 \pm 9.54$ \\
\hline Pack years of smoking & $8.48 \pm 11.44$ \\
\hline Random blood sugar & $165.9 \pm 53.15$ \\
\hline Total cholesterol & $182.43 \pm 37.76$ \\
\hline CRP & $8.05 \pm 4.33$ \\
\hline Table 4: General Characteristics of Study Population \\
\hline
\end{tabular}

\begin{tabular}{|c|c|}
\hline Parameter & Percentage \\
\hline Male & $65 \%$ \\
\hline Female & $35 \%$ \\
\hline Hypertension & $41.67 \%$ \\
\hline Diabetes mellitus & $28.33 \%$ \\
\hline Dyslipidaemia & $43.33 \%$ \\
\hline CRP $>6$ & $70 \%$ \\
\hline Ischaemic & $68.33 \%$ \\
\hline Haemorrhagic & $31.67 \%$ \\
\hline Table 5: General Characteristics of Study Population \\
\hline
\end{tabular}

Based on NIHSS scale, patients were classified as mild (07), moderate (8-14) and severe stroke (>14).[7,8] Short-term outcome was measured by modified Rankin scale and Barthel ADL Index (BI) at 7 days. Poor outcome was defined as mRS $>2$. . $^{9-11]}$ and $\mathrm{BI}<95 .{ }^{[12]}$

According to NIHSS scale, $13.3 \%$ of patients had mild stroke and $48.3 \%$ and $28.3 \%$ of patients had moderate and severe stroke respectively. Based on mRS done at 7 days, $21.67 \%$ of patients had favourable outcome and $78.3 \%$ of patients had poor outcome. The mean NIHSS score was $13.23 \pm 4.49$. The mean mRS for the study population is $3.67 \pm 1.25$. Based on $\mathrm{BI}, 18.33 \%$ of patients had favourable outcome and $81.67 \%$ of patients had poor outcome (Fig. 1). 


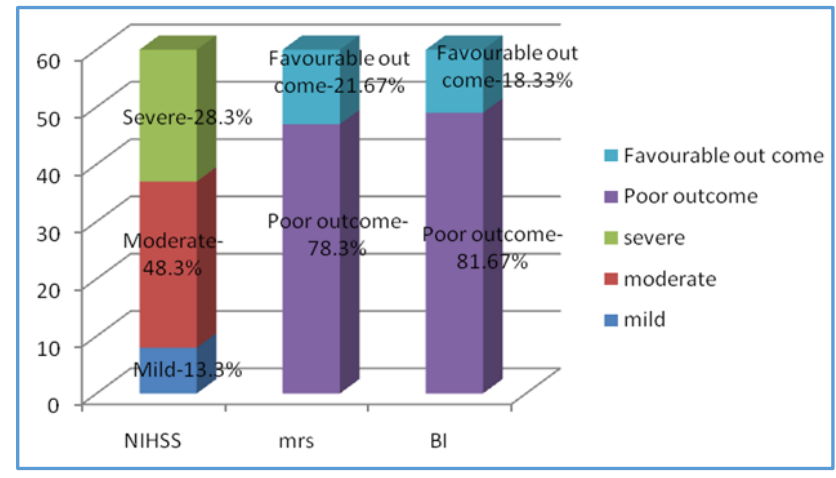

Fig. 1: Severity of Stroke in Study Population

The mean CRP levels in Ischaemic stroke was $8.56 \pm 3.51$, while that of haemorrhagic stroke is $6.95 \pm 5.67$. The demographic details of both ischaemic and haemorrhagic stroke is shown in Table 6.

\begin{tabular}{|c|c|c|}
\hline & $\begin{array}{c}\text { Ischaemic } \\
\text { Stroke }\end{array}$ & $\begin{array}{c}\text { Haemorrhagic } \\
\text { Stroke }\end{array}$ \\
\hline Age & $63.1 \pm 9.59$ & $61.32 \pm 9.59$ \\
\hline Male & 24 & 15 \\
\hline Female & 17 & 4 \\
\hline Diabetes mellitus & 12 & 5 \\
\hline Dyslipidaemia & 16 & 10 \\
\hline Hypertension & 11 & 14 \\
\hline Pack years of Smoking & $7.68 \pm 10.96$ & $10.21 \pm 12.54$ \\
\hline Alcoholic & 10 & 6 \\
\hline CRP & $8.56 \pm 3.51$ & $6.95 \pm 5.67$ \\
\hline Total cholesterol & $182.2 \pm 35.45$ & $182.95 \pm 43.37$ \\
\hline RBS & $167.63 \pm 56.46$ & $162.16 \pm 46.41$ \\
\hline \multicolumn{3}{|c|}{$\begin{array}{c}\text { Table 6: Demographic Data in Ischaemic } \\
\text { and Haemorrhagic Stroke }\end{array}$} \\
\hline
\end{tabular}

There was positive correlation between CRP levels and NIHSS in Ischaemic stroke ( $\mathrm{r}=0.44 ; \mathrm{p}=0.004$ (Fig. 2)). CRP levels in severe ischaemic stroke based on NIHSS was $10.85 \pm 3.85$, while in mild and moderate stroke it was $7.50 \pm 2.82$ ( $\mathrm{p}$ value $=0.012$ ). MRS also had a positive correlation with CRP ( $\mathrm{r}=0.35$; $\mathrm{p}$ value $=0.022$ ) (Fig. 3), while BI had negative correlation with CRP in ischaemic stroke ( $r=0.54$; $p$ value $<0.001$ ) (Fig. 4).

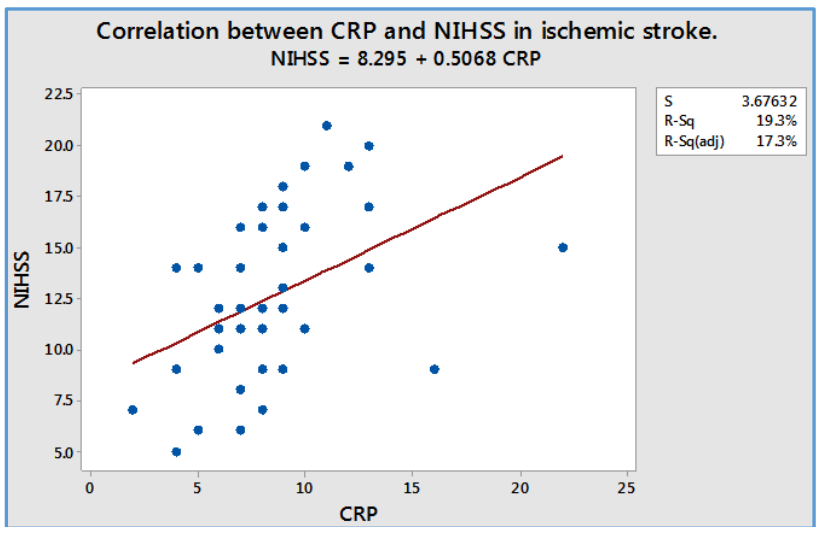

Fig. 2

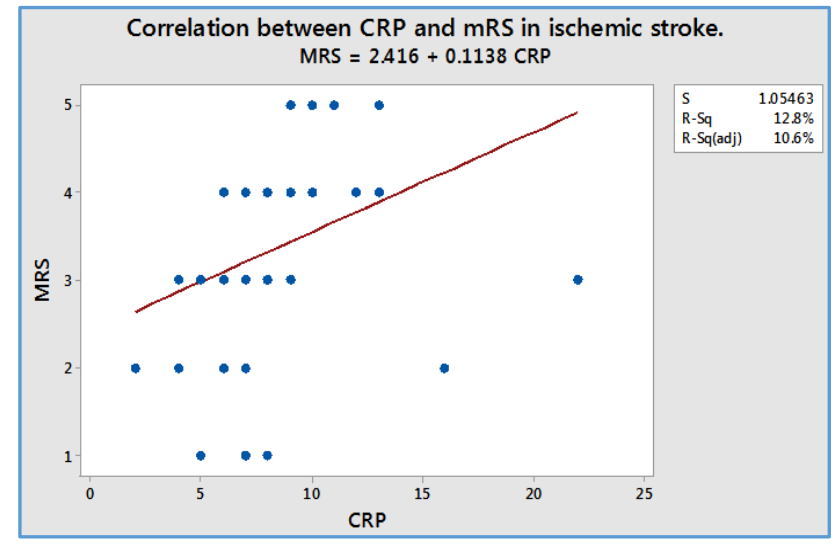

Fig. 3

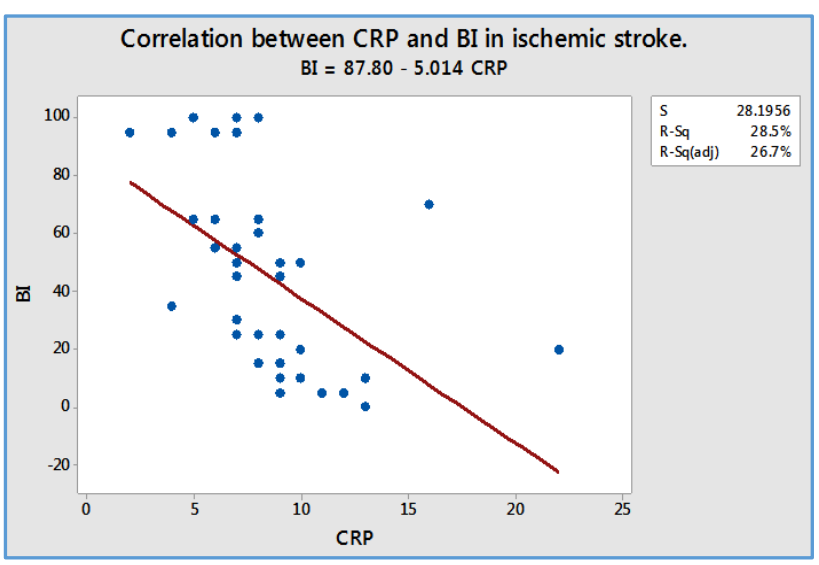

Fig. 4

In haemorrhagic stroke, the correlation between CRP and NIHSS was not significant ( $\mathrm{r}=0.304 ; \mathrm{p}$ value $=0.203$ ) (Fig. 5). The mean CRP levels in severe haemorrhagic stroke is $6.7 \pm 4.32$, while in mild and moderate stroke it is $7.22 \pm 7.16$ (p value $=0.853$ ). There was no significant correlation between $\mathrm{mRS}$ and CRP levels in haemorrhagic stroke $(\mathrm{r}=0.31 ; \mathrm{p}$ value $=0.201$ ) (Fig. 6) as well as BI and CRP levels (Fig. 7).

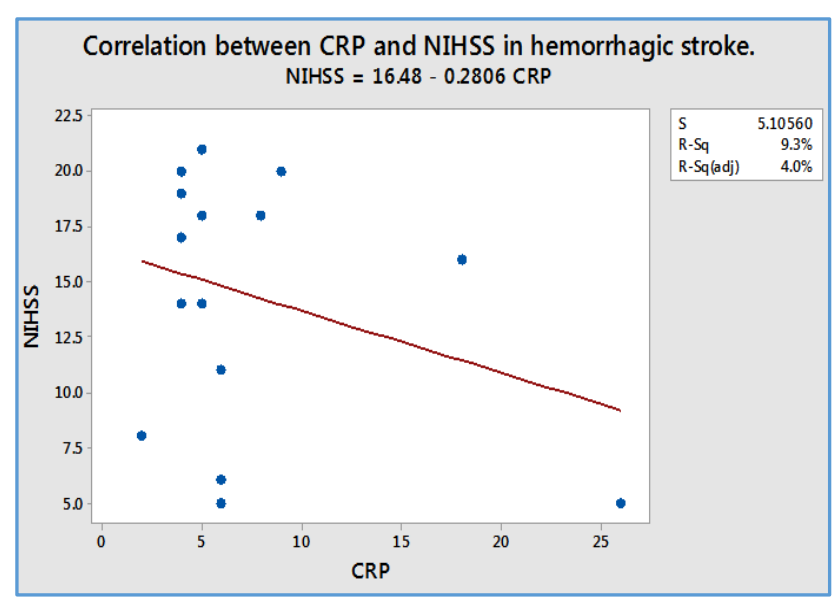

Fig. 5 


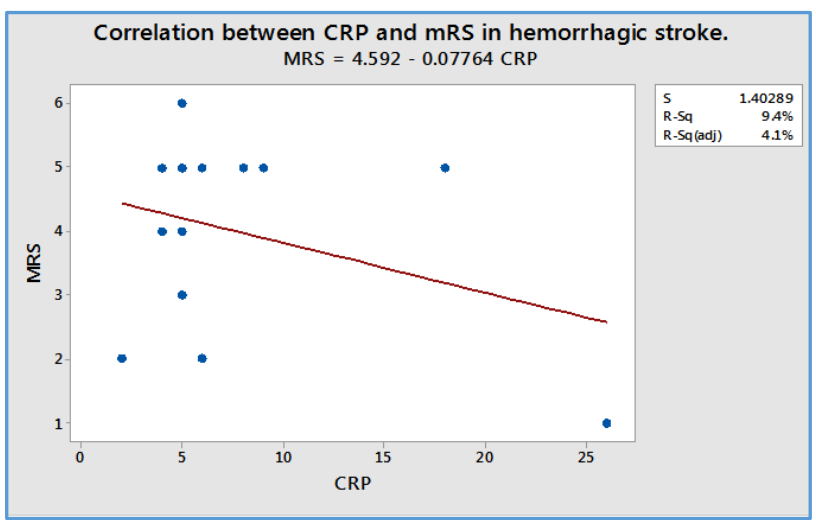

Fig. 6

Comparing both ischaemic and haemorrhagic stroke, CRP levels were higher in ischaemic stroke than haemorrhagic stroke. CRP levels significantly correlated with severity of stroke in ischaemic stroke, while in haemorrhagic stroke the association was not significant (Table 7).

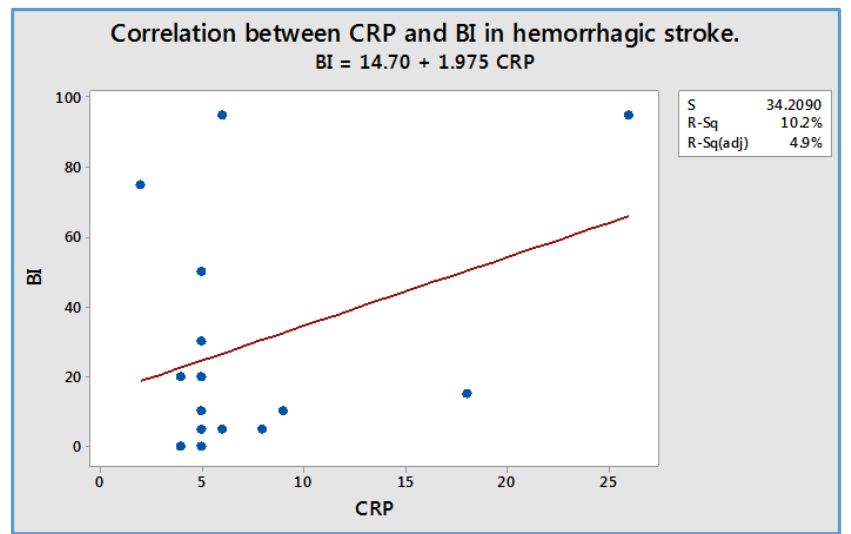

Fig. 7

\begin{tabular}{|c|c|c|c|c|c|}
\hline \multirow{2}{*}{\multicolumn{2}{|c|}{ Criteria }} & \multicolumn{2}{|c|}{ Ischaemic Stroke } & \multicolumn{2}{|c|}{ Haemorrhagic Stroke } \\
\hline & & \multirow{2}{*}{$\begin{array}{c}\text { Mean with SD } \\
7.50+/-2.82\end{array}$} & \multirow{3}{*}{$\begin{array}{c}\text { P value } \\
\text { P-Value }= \\
0.012\end{array}$} & Mean with SD & P value \\
\hline \multirow{2}{*}{ NIHSS } & Mild and moderate & & & $7.22+/-7.16$ & \multirow{2}{*}{$\begin{array}{c}\mathrm{P}-\text { Value }= \\
0.853\end{array}$} \\
\hline & Severity & $10.85+/-3.85$ & & $6.70+/-4.32$ & \\
\hline \multirow{2}{*}{ MRS } & Poor outcome & $9.13+/-3.20$ & \multirow{2}{*}{$\begin{array}{c}\mathrm{P}-\text { Value }= \\
0.014\end{array}$} & $6.13+/-3.58$ & \multirow{2}{*}{$\begin{array}{c}\mathrm{P}-\text { Value }= \\
0.532\end{array}$} \\
\hline & Favourable outcome & $6.56+/-4.00$ & & $10.0+/-10.8$ & \\
\hline \multirow{2}{*}{ BI } & Poor outcome & $9.33+/-3.37$ & \multirow{2}{*}{$\begin{array}{c}\text { P-Value < } \\
0.001\end{array}$} & $5.88+/-3.61$ & \multirow{2}{*}{$\begin{array}{c}\mathrm{P}-\text { Value }= \\
0.419\end{array}$} \\
\hline & Favourable outcome & $5.38+/-2.00$ & & $12.7+/-11.5$ & \\
\hline
\end{tabular}

\section{DISCUSSION}

Stroke is the leading cause of disability in both developed and developing countries. It is the third most common cause of death.[13] Atherosclerosis with rupture of plaque is the most important cause of stroke. Inflammation is a central process in the initiation, development and subsequent rupture of plaques. As the plaques are developing, there is recruitment of immune cells such as macrophages and $\mathrm{T}$ cells. These cells produce various inflammatory mediators including cytokines, proteases and free radicals which ultimately cause rupture of plaque.[14] Brain damage further causes mobilization and migration of cells such as neutrophils and macrophages into the affected area and stimulates inflammatory response.

C-Reactive protein is produced by liver. It is usually absent in blood. Its production is stimulated by acute inflammation and usually rises within the first few hours of inflammation.[15] Our study was done to demonstrate the association between CRP levels and severity of stroke.

NIHSS was used in this study to assess severity. Various studies have concluded that it is predictive of stroke outcomes.[16-18] One study demonstrated that severity of stroke assessed by NIHSS at admission to be predictive of 3 month mortality and another study established it as an independent predictor of 30 days mortality.

We found that CRP levels is a predictor of severity and short-term outcome in ischaemic stroke patients. CRP levels did not correlate with severity in haemorrhagic stroke. CRP levels were positively correlated with NIHSS and mRS in ischaemic stroke. It had negative correlation with BI in ischaemic stroke.

Various studies have found an association between CRP levels and stroke. Di Napoli et al demonstrated in his study that concentration of CRP increased in the first 24 hours following stroke and this rise is associated with infarct size and hence associated with poor prognosis.[19]

Di Napoli in another study found that CRP cannot be used in the risk stratification of stroke.[20] Recent studies found that increased CRP levels predicted recurrence of stroke and transient ischaemic attack.

The exact mechanism for the elevation of CRP levels in severe stroke remains unexplained. Atherothrombosis being an inflammatory pathology could cause rise in acute phase reactants in the first few hours.[15] Also, cerebral tissue injury can cause elevated CRP.[21] Activation of coagulation by increased CRP through tissue factor expression has also been proposed as one of the possibilities.[22] CRP, being an inflammatory marker could be associated with other pathological processes that might cause severe stroke. Some studies have shown that CRP per se can cause secondary brain damage due to complement activation. [23]

In the above context, whether increased CRP leads to severe stroke or vice versa needs to be ascertained through larger population based studies.

The lack of inflammatory process preceding the onset of haemorrhagic stroke could well explain the finding in our study that there is no significant correlation between CRP and severity of haemorrhagic stroke. However, certain studies found as association between increased CRP and size of haematoma in haemorrhagic stroke. The probable mechanism could be the inflammatory response that occurs because of tissue injury as a result of haemorrhage.[24] This leads to IL6 production, one of the major stimulus for CRP synthesis.[25] 
We found that although CRP levels are elevated in haemorrhagic stroke, there was no correlation with severity of stroke. Elevated CRP levels in haemorrhagic stroke is a consequence of tissue injury and does not involve in the pathogenesis. Our study revealed that rise in CRP level is more in ischaemic stroke than in haemorrhagic stroke. Other studies have also reached a similar conclusion. [26,27]

This study has few limitations. We did not correlate the radiologic finding of CT Brain such as the size of the haemorrhage with CRP levels, as we intended to find the clinical outcome.

Another limitation is that we used a single value of CRP at the time of admission for predicting severity rather than serial measurements, which could have been more informative. Another limitation is the use of regular CRP rather than using high sensitivity CRP. The regular CRP is commonly present and readily available in most ICU setups across our country.

\section{CONCLUSION}

CRP levels measured within 24 hours of admission are elevated in both ischaemic and haemorrhagic stroke. It is a predictor for severe stroke and unfavourable outcome in ischaemic stroke, but not in haemorrhagic stroke.

\section{REFERENCES}

1. Jauch EC, Saver JL, Adams HP, et al. Guidelines for the early management of patients with acute ischaemic stroke: a guideline for healthcare professionals from the American heart association/American stroke association. Stroke 2013;44(3):870-947.

2. denHertog HM, Rossum JA, Worp HB, et al. C-reactive protein in the very early phase of acute ischaemic stroke: association with poor outcome and death. J Neurol 2009;256(12):2003-8.

3. Gill R, Kemp JA, Sabin C, et al. Human C-reactive protein increases cerebral infarct size after middle cerebral artery occlusion in adult rats. J Cereb Blood Flow Metab 2004;24(11):1214-8.

4. Rost NS, Wolf PA, Kase CS, et al. Plasma concentration of Creactive protein and risk of ischaemic stroke and transient ischaemic attack: the Framingham study. Stroke 2001;32(11):2575-9.

5. Bos MJ, Schipper CM, Koudstaal PJ, et al. High serum Creactive protein level is not an independent predictor for stroke: the Rotterdam study. Circulation 2006;114(15): 1591-8.

6. Di Napoli M, Godoy DA, Campi V, et al. C-reactive protein in intracerebral haemorrhage: time course, tissue localization, and prognosis. Neurology 2012;79(7):690-9.

7. Brott T, Adams HP, Olinger CP, et al. Measurements of acute cerebral infarction: a clinical examination scale. Stroke 1989;20(7):864-70.

8. Adams HP, Davis PH, Leira EC, et al. Baseline NIH stroke scale score strongly predicts outcome after stroke: a report of the trial of org 10172 in acute stroke treatment (TOAST). Neurology 1999;53(1):126-31.
9. Rankin J. Cerebral vascular accidents in patients over the age of 60 III diagnosis and treatment. Scott Med J 1957;2(6):254-68.

10. Bonita R, Beaglehole R. Recovery of motor function after stroke. Stroke 1988;19(12):1497-500.

11. vanSwieten JC, Koudstaal PJ, Visser MC, et al. Interobserver agreement for the assessment of handicap in stroke patients. Stroke 1988;19(5):604-7.

12. Collin C, Wade DT, Davies S, et al. The Barthel ADL index: a reliability study. Int Disabil Studies 1988;10(2):61-3.

13. Feigin VL. Stroke epidemiology in the developing world. Lancet 2005;365(9478):2160-1.

14. Hansson GK, Libby P. The immune response in atherosclerosis: a double-edged sword. Nat Rev Immunol 2006;6(7):508-19.

15. Ridker PM, Silvertown JD. Inflammation, C-reactive protein, and atherothrombosis. J Periodontol 2008;79 (Suppl 8):1544-51.

16. Dhamoon MS, Moon YP, Paik MC, et al. Long-term functional recovery after first ischaemic stroke: the northern Manhattan study. Stroke 2009;40(8):2805-11.

17. Johnston $\mathrm{KC}$, Connors AF, Wagner DP. A predictive risk model for outcomes of ischaemic stroke. Stroke 2000;31(2):448-55.

18. Hénon H, Godefroy O, Leys D, et al. Early predictors of death and disability after acute cerebral ischaemic event. Stroke 1995;26(3):392-8.

19. DiNapoli M. Early inflammatory response in ischaemic stroke. Thromb Res 2001;103(3):261-4.

20. DiNapoli M, Schwaninger M, Cappelli R, et al. Evaluation of $\mathrm{C}$-reactive protein measurement for assessing the risk and prognosis in ischaemic stroke: a statement for health care professionals from the CRP pooling project members. Stroke 2005;36(6):1316-29.

21. Audebert HJ, Rott MM, Eck T, et al. Systemic inflammatory response depends on initial stroke severity, but is attenuated by successful thrombolysis. Stroke 2004;35(9):2128-33.

22. Cermak J, Key NS, Bach RR, et al. C-reactive protein induces human peripheral blood monocytes to synthesize tissue factor. Blood 1993;82(2):513-20.

23. Pepys MB, Hirschfield GM, Tennent GA, et al. Targeting Creactive protein for the treatment of cardiovascular disease. Nature 2006;440(7088):1217-21.

24. Aronowski J, Zhao X. Molecular pathophysiology of cerebral haemorrhage: secondary brain injury. Stroke 2011;42(6):1781-6.

25. Kuhlmann CR, Librizzi L, Closhen D, et al. Mechanisms of C-reactive protein-induced blood-brain barrier disruption. Stroke 2009;40(4):1458-66.

26. Roudbary SA, Saadat F, Forghanparast K, et al. Serum Creactive protein level as a biomarker for differentiation of ischaemic from haemorrhagic stroke. Acta Med Iran 2011;49(3):149-52.

27. Montaner J, Mendioroz M, Delgado P, et al. Differentiating ischaemic from haemorrhagic stroke using plasma biomarkers: the S100B/RAGE pathway. J Proteom 2012;75(15):4758-65. 